\title{
Serum Ionized Calcium Variations in Simple and Comminuted Fractures in the Dog's Appendicular Skeleton and Consequent Risks of a Hypercalcemic Condition
}

\author{
Gonçalo Cabral Neto ${ }^{1,4}$, Catarina Lavrador ${ }^{3}$, Pedro Azevedo ${ }^{4}$, L. Miguel Carreira ${ }^{1,2,4,5 *}$ \\ ${ }^{1}$ Faculty of Veterinary Medicine, University of Lisbon (FMV/ULisboa) - Portugal \\ ${ }^{2}$ Interdisciplinary Centre for Research in Animal Health (CIISA) - University of Lisbon, (FMV/ULisboa) - \\ Portugal \\ ${ }^{3}$ Institute of Mediterranean Agricultural and Environmental Science (ICAAM) - School of Science and \\ Technology (ECT), University of Évora - Portugal \\ ${ }^{4}$ Anjos of Assis Veterinary Medicine Centre (CMVAA), Barreiro - Portugal \\ ${ }^{5}$ Human Dental Clinical, Lisboa - Portugal
}

\begin{abstract}
*Corresponding Author: L.Miguel Carreira, Department of Clinics, Professor of Surgery I and II, Faculty of Veterinary Medicine, University of Lisbon (FMV-ULisboa), Lisbon, Portugal, Email: miguelcarreira@fmv.ulisboa.pt
\end{abstract}

\begin{abstract}
Background: A sample of 40 Canis familiaris $(n=40)$ of both genders and all breeds was used. The sample was divided in two groups: control group $(C G)$ with trauma but no fractures, and the study group with appendicular skeleton fractures $(F G)$ subdivided in two groups according to the type of fracture: simple fracture $(S F G)$ and comminuted fracture $(C F G)$.
\end{abstract}

Objectives: The study aimed: 1) to evaluate the variations on serum ionized $\mathrm{Ca}^{2+}\left(\left[\mathrm{iCa}{ }^{2+}\right]\right)$ concentrations between patients with simple fractures $(S F)$ and comminuted fractures $(C F)$, and 2) to establish the existence of a relationship between the $S F$ and $C F$ with the patients'clinical signs.

Methods: $\left[i \mathrm{Ca}^{2+}\right]$ measurement was achieve with the analytic system CG8+, through $i$-STAT®, Abbott ${ }^{\circledR}$. Patients were assessed for clinical signs and symptoms associated with potential hypercalcaemia.

Results: Results were statistically significant for $p$ values $<0.05$. Patients with $S F$ and $C F$ always presented a higher average concentration of $\left[i \mathrm{Ca}^{2+}\right]$ compared to the $C T$, but no statistical significant differences were registered between the $S F$ and $C F$.

Conclusions: $S F$ and $C F$ patients a mild hypercalcemia condition should be always considered until laboratory results proven the contrary. $C F$ patients presented significant higher expression of clinical signs compared with SF ones. As a result, the measurement of $\left[\mathrm{iCa}^{2+}\right]$ concentrations should always be a included on basic laboratory panel required by clinicians in patients with fracture, and the use of drugs that promote the extracellular $\mathrm{Ca}^{2+}$ rising should be avoid until the $\left[\mathrm{iCa}^{2+}\right]$ is properly monitored in order to promote patients safety.

Keywords: Dog; Serum ionized calcium; Fracture; Trauma; Hypercalcemia

\section{INTRODUCTION}

Bone is a highly dynamic biological structure involved in a lifelong remodeling process, adapting itself under the influence of numerous intrinsic and extrinsic factors either activating or inhibiting its own cells though processes of formation, remodeling and reabsorption. Bone consist of approximately $25.0 \%$ of water, $45.0 \%$ of ashes, and $30.0 \%$ of organic substance, being calcium $\left(\mathrm{Ca}^{2+}\right)$ the most abundant and important component since it reaches almost $37.0 \%$ of the inorganic component ${ }^{1,} \quad{ }^{2} \cdot \mathrm{Ca}^{2+}$ plays a fundamental role on a multiplicity of physiological processes ${ }^{3}$, whilst is stored on bone tissue under the form of hydroxyapatite crystals $\left[\mathrm{Ca}_{10}\left(\mathrm{PO}_{4}\right)_{6}(\mathrm{OH})_{2}\right]$, representing $98.0 \%$ 
of the total amount of $\mathrm{Ca}^{2+}$ stored. The remaining $2.0 \%$ is a "safety deposit" for the control of physiological concentrations of serum $\mathrm{Ca}^{2+}$. Half of this amount is in the intracellular space, in circulation or in the interstitial tissue, within a complex with inorganic non-ionized elements, dependent on the fluctuations of the blood's acid-base balance. The remaining half is in the extracellular fluid in the form of serum ionized $\mathrm{Ca}^{2+}\left(\left[\mathrm{iCa}^{2+}\right]\right)^{2}$. Orthopedic trauma represents an important component of most common traumas among companion small animal, most frequently represented by different types of fractures. In what concerns the specific type of fracture and thus the extension of the affected bone area, we can classify them in simple fractures (with only one line of fracture) or comminuted fractures (with more than one line of fracture) $)^{4}$. During the bone repair process, the $\left[\mathrm{iCa}^{2+}\right]$ shows two types of movements: 1) from bone to blood, and 2) from intracellular and extracellular space fluid to bone. Over the fracture line, and intending to widen it, osteoclasts reabsorb the bone top ends and loose fragments that result from the traumatic process. This phenomenon occurs until the third and fourth week post-fracture, according to the radiographic image. Hydroxyapatite is therefore degraded and the $\mathrm{Ca}^{2+}$ ions are then released to the bloodstream on its soluble way. Mineralization of bone fragments and the callus development in the osteogenic tissue occurs due to the $\mathrm{Ca}^{2+}$ salts deposition into the matrix. This $\mathrm{Ca}^{2+}$ owes its origin from the osteoblast's mitochondrial vesicles, and the $\mathrm{Ca}^{2+}$ supersaturated extracellular fluid adjacent to the organic matrix $^{5,6,7}$.

In $\mathrm{dog}$, it is accepted that $\left[\mathrm{iCa}^{2+}\right]$ levels over $1.45 \mathrm{mmol} / \mathrm{L}$ are associated with a hypercalcemia condition, being the clinical signs expressed only when the $\left[\mathrm{iCa}^{2+}\right]$ levels are above $1.8 \mathrm{mmol} / \mathrm{L}^{8,9}$. Patients' clinical signs severity depends on the level and duration of the hypercalcemia state ${ }^{9}$. Acidosis will also magnify the effects of hypercalcemia by raising the ratio of calcium in the ionized fraction ${ }^{10}$. Of all the affected systems, neuromuscular, gastrointestinal, renal and cardiovascular are the most clinically important ones, expressed by lethargy, anorexia, vomiting, constipation, muscle weakness, muscular shivering, polydipsia/polyuria (PU/PD), and convulsions ${ }^{9}$ $10,11,12,13,14,15$.
The study used a sample of 40 dogs, and aimed: 1) to evaluate the variations on $\left[\mathrm{iCa}^{2+}\right]$ concentrations between patients with simple fractures (SF) and comminuted fractures (CF), and 2) to establish the existence of a relationship between the clinical signs presented by the patients and the presence of SF or a CF condition.

\section{MethodS AND MATERIALS}

The study included a sample composed of 40 Canis familiaris $(\mathrm{n}=40)$ of both genders, and no breed predilection, evaluated at the Veterinary Teaching Hospital of Faculty of Veterinary Medicine, University of Lisbon - Portugal, and at Anjos of Assis Veterinary Medicine Centre (CMVAA), Barreiro - Portugal. Study only started after obtaining a written agreement from the patients' owners to pursue it, and approved by the Institutional Ethical Committee for Analysis of Research Projects - CEBEA. Sample was divided in two groups: control group (CG) composed of 10 patients with trauma but no fractures $(n=10)$ and the study group with appendicular skeleton fractures $(\mathrm{FG})$ composed of 30 patients $(n=30)$. Inclusion criteria were: age over 9 months; forelimb or hind limb complete fracture with one fracture line (simple) or more than two fracture lines (comminuted) confirmed by two radiographic projections (latero-lateral and cranial-caudal); trauma with less than $48 \mathrm{~h}$; absence of preexistent disease or medications that could somehow interfere with $\mathrm{Ca}^{2+}$ metabolism. In non-neutered females, they were only included as long as they were not showing any signs of estrus. The CG allows us to characterize the $\left[\mathrm{iCa}^{2+}\right]$ concentration in dogs with trauma but no fracture, simply to rule out the effects of trauma in general and thus be used as reference guide to the comparison with the FG.

Two groups were considered according to the type of fracture: simple fracture group (SFG) and comminuted fracture group (CFG), each with 15 animals. Patients were assessed for clinical signs and symptoms associated with potential hypercalcaemia, and submitted to an adequate analgesic protocol that consisted of methadone $0.1 \mathrm{mg} / \mathrm{Kg} / \mathrm{IM}$, and carprofen $4 \mathrm{mg} / \mathrm{Kg} / \mathrm{SC}$. Using lithium heparin tubes (BD Vacutainer $($ ) a blood sample was drawn from the cephalic vein to all patients from all groups (CG, SFG, CFG) to do a $\left[\mathrm{iCa}^{2+}\right]$ measurement in order to achieve a basic clinical evaluation. Blood samples were studied according to 
analytic system CG8+, Abbott@. This system uses the positive selective electrode based on Nernst equation to evaluate $\mathrm{iCa}^{2+}$ electrochemical potential and results are later interpreted through i-STAT ®. Normal reference concentration fall between 1.12-1.32 $\mathrm{mmol} / \mathrm{L}$ and the final results are already adjusted to a $\mathrm{pH}$ of 7,4 . $\mathrm{R}$ ( software, version 3.0.1 was the data statistical analysis that also included a descriptive statistical of CG, FG, SFG, and CFG of the $\left[\mathrm{iCa}^{2+}\right]$ variable. ShapiroWilk test was used to evaluate the normality of studied data. To non-rejected variables, 2 samples $\mathrm{t}$ test for Welch solution was the method used to search for existent differences between $\left[\mathrm{iCa}^{2+}\right]$ concentration within the $\mathrm{CG}$ and FG and between SFG and CFG. To confirm statistical significant differences of $\left[\mathrm{iCa}^{2+}\right]$ concentration between FG and the method's maximum reference guide value, we used one sample t-test. Results were statistically significant for $\mathrm{p}$ values $<0.05$. 95\% value was used on the evaluation of the confidence intervals. To compare each clinical sign between the CG and FG, and between the SFG and CFG, Fisher's exact test was used for count data in order to determine statistical significant differences, as well as the odds.

\section{ReSUltS}

Obtained results are listed on Table 1. ShapiroWilk test allowed us to state the presence of normality on the concentration of ionized calcium in all studied groups: $\mathrm{CG}(p=0.80) ; \mathrm{FG}$ $(p=0.22)$; SFG $(p=0.98)$ and CFG $(p=0.09)$. Welsh t-test allowed us to make a comparison between concentrations of ionized calcium in all groups and this led us to the conclusion that the difference among groups were statistically significant $(p=0.00)$ (Figure 1). However, the use of Welsh t-test to compare obtained concentrations of ionized calcium between SFG and CFG did not allowed us to obtain statistically significant differences since $p=0.06$ (Figure 2). On table 2 are listed the p-value obtained with the Fisher's test for the clinical signs comparison between the groups. No statistically significant differences were registered between the $\mathrm{CG}$ and the $\mathrm{FG}$ to considering all clinical signs $(p>0.05)$. Despite that, Fisher's test allowed us to confirm that the odds of having anorexia, lethargy and muscular shivering were $54.0 \%$, twice, and $93.0 \%$ higher respectively in the FG compared with subjects of the CG. In what concerns patients' clinical signs, no statistically significant differences were registered between the SFG and the CFG for anorexia, muscular shivering, vomiting and constipation, opposed to what was observed for lethargy $(p=0.01)$ and PU/PD $(p=0.00)$. In this comparison, CFG specimens presented the odds of having muscular shivering one third more times, vomiting and constipation twice times, anorexia three times, PU/PD twelve times, and lethargy fourteen times higher than the SFG.

Table1. Sample descriptive statistics of serum ionized calcium $\left[\mathrm{iCa}^{2+}\right](\mathrm{mmol} / \mathrm{L})$ in the control, study, simple fracture and comminuted fracture groups

\begin{tabular}{|c|c|c|c|c|c|c|}
\hline Paremeter & Group & $\mathbf{n}$ & Mean & SD & $\max$ & $\min$ \\
\hline Gender & $\begin{array}{l}\text { CG } \\
\text { FG }\end{array}$ & $\begin{array}{l}10 \\
30\end{array}$ & $\begin{array}{c}6 \text { male } \\
21 \text { male }\end{array}$ & $\begin{array}{c}4 \text { female } \\
19 \text { female }\end{array}$ & $\begin{array}{l}- \\
-\end{array}$ & $\begin{array}{l} \\
-\end{array}$ \\
\hline $\begin{array}{c}\text { Age } \\
\text { (Years) }\end{array}$ & $\begin{array}{l}\text { CG } \\
\text { FG }\end{array}$ & $\begin{array}{l}10 \\
30\end{array}$ & $\begin{array}{l}4.25 \\
5.95\end{array}$ & $\begin{array}{l}4.59 \\
6.71\end{array}$ & $\begin{array}{c}1 \\
1.2\end{array}$ & $\begin{array}{c}7.5 \\
10.7\end{array}$ \\
\hline $\begin{array}{l}\text { Body weight } \\
(\mathrm{Kg})\end{array}$ & $\begin{array}{l}\text { CG } \\
\text { FG }\end{array}$ & $\begin{array}{l}10 \\
30\end{array}$ & $\begin{array}{l}14.85 \\
18.18\end{array}$ & $\begin{array}{c}8.69 \\
10.85\end{array}$ & $\begin{array}{c}8.7 \\
10.5\end{array}$ & $\begin{array}{c}21 \\
25.85\end{array}$ \\
\hline Breed & CG & $\begin{array}{l}5 \\
2 \\
3\end{array}$ & $\begin{array}{c}\text { Crossbreed } \\
\text { French Bulldogue } \\
\text { Poodle }\end{array}$ & $\begin{array}{l}- \\
- \\
-\end{array}$ & $\begin{array}{l}- \\
- \\
-\end{array}$ & $\begin{array}{l}- \\
- \\
-\end{array}$ \\
\hline & FG & $\begin{array}{l}13 \\
8 \\
4 \\
2 \\
3 \\
3\end{array}$ & $\begin{array}{l}\text { Crossbreed } \\
\text { Poodle } \\
\text { Boxer } \\
\text { Beagle } \\
\text { Siberian husky }\end{array}$ & $\begin{array}{l}- \\
- \\
- \\
- \\
-\end{array}$ & $\begin{array}{l}- \\
- \\
- \\
- \\
-\end{array}$ & $\begin{array}{l}- \\
- \\
- \\
- \\
-\end{array}$ \\
\hline & & & & \multicolumn{3}{|c|}{$\mathbf{n}$} \\
\hline & & $\mathbf{n}$ & Clinical Signs & Total & SFG & CFG \\
\hline $\begin{array}{c}\text { Clinical signs } \\
\text { potential associated } \\
\text { with hypocalcaemia }\end{array}$ & CG & 10 & $\begin{array}{l}\text { Anorexia } \\
\text { Lethargy } \\
\text { Muscular shivering }\end{array}$ & $\begin{array}{l}3 \\
5 \\
7\end{array}$ & $\begin{array}{l}- \\
- \\
-\end{array}$ & $\begin{array}{l}- \\
- \\
-\end{array}$ \\
\hline
\end{tabular}


Serum Ionized Calcium Variations in Simple and Comminuted Fractures in the Dog's Appendicular Skeleton and Consequent Risks of a Hypercalcemic Condition

\begin{tabular}{|c|c|c|c|c|c|c|}
\hline & FG & 30 & $\begin{array}{l}\text { Anorexia } \\
\text { Vomiting } \\
\text { Constipation } \\
\text { Lethargy } \\
\text { PD/PU } \\
\text { Muscular shivering }\end{array}$ & $\begin{array}{c}12 \\
3 \\
9 \\
21 \\
18 \\
17\end{array}$ & $\begin{array}{l}4 \\
1 \\
3 \\
4 \\
5 \\
8\end{array}$ & $\begin{array}{c}8 \\
2 \\
6 \\
17 \\
13 \\
9\end{array}$ \\
\hline & & $\mathbf{n}$ & Mean & SD & $\max$ & $\min$ \\
\hline$\left[\mathrm{iCa}^{2+}\right](\mathrm{mmol} / \mathrm{L})$ & $\begin{array}{l}\text { CG } \\
\text { FG }\end{array}$ & $\begin{array}{l}10 \\
30\end{array}$ & $\begin{array}{l}1.201 \\
1.462\end{array}$ & $\begin{array}{l}0.044 \\
0.162\end{array}$ & $\begin{array}{l}1.260 \\
1.890\end{array}$ & $\begin{array}{l}1.120 \\
1.170\end{array}$ \\
\hline $\begin{array}{c}{\left[\mathrm{iCa}^{2+}\right](\mathrm{mmol} / \mathrm{L})} \\
\text { and type of fracture }\end{array}$ & $\begin{array}{l}\text { SFG } \\
\text { CFG }\end{array}$ & $\begin{array}{l}15 \\
15\end{array}$ & $\begin{array}{l}1.408 \\
1.516\end{array}$ & $\begin{array}{l}0.123 \\
0.181\end{array}$ & $\begin{array}{l}1.620 \\
1.890\end{array}$ & $\begin{array}{l}1.170 \\
1.170\end{array}$ \\
\hline
\end{tabular}

Data dispersion (SD) measures obtained in a 95\% confidence interval(CI). presenting the minimum (min) and maximum (max) values in the sample considered. Control group (CG); Study group (FG); Simple fracture group (SFG) and comminuted fracture group (CFG).

Table2. Comparison for the clinical signs between the control and the fracture groups, and between the simple and communited fracture groups. P-value $<0.05$ are statistically significant

\begin{tabular}{|c|c|c|}
\hline Clinical Sign & $\begin{array}{c}\text { FG vs CG } \\
\text { p-value }\end{array}$ & $\begin{array}{c}\text { CFG vs SFG } \\
\text { p-value }\end{array}$ \\
\hline Anorexia & 0.71 & 0.26 \\
\hline Lethargy & 0.27 & 0.01 \\
\hline Muscular shivering & 0.47 & 1.00 \\
\hline Vomiting & - & 1.00 \\
\hline Constipation & - & 0.42 \\
\hline PU/PD & - & 0.00 \\
\hline
\end{tabular}

Control group (CG); Study group (FG); Simple fracture group (SFG) and comminuted fracture group $(C F G)$.

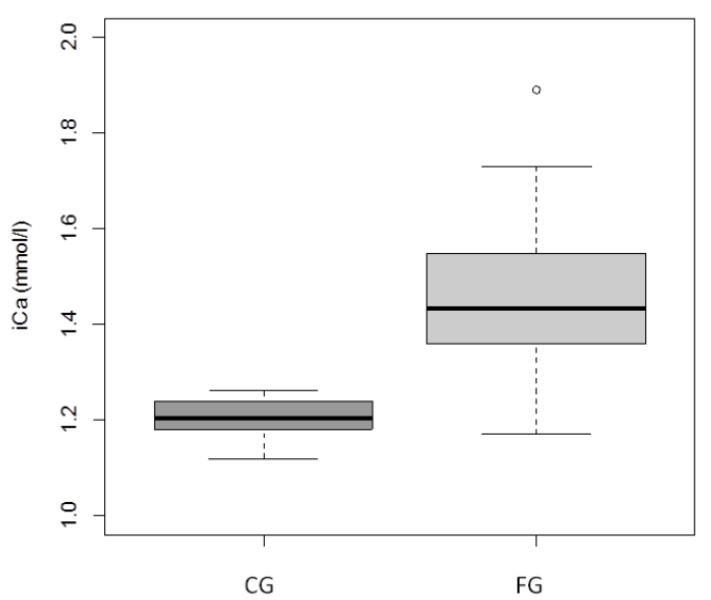

Figure1. Boxplot of characteristics of the $C G$ and $F G$

\section{DISCUSSION}

According to the results it is possible to conclude that patients from groups FG, SFG and CFG) always showed a higher average concentration of $\left[\mathrm{iCa}^{2+}\right]$ compared to $\mathrm{CG}$, showing concentrations within a range of 1.17 $\mathrm{mmol} / \mathrm{L}$ to $1.89 \mathrm{mmol} / \mathrm{L}$. It is clear with this study, that patients among FG can be considered to have a mild hypercalcemia condition by having shown clinical signs associated with this condition.

Contrary to what was observed on group $\mathrm{CFG}$, patients from group SFG showed no $\left[\mathrm{iCa}^{2+}\right]$ higher than $1.8 \mathrm{mmol} / \mathrm{L}$. This fact leads us to the

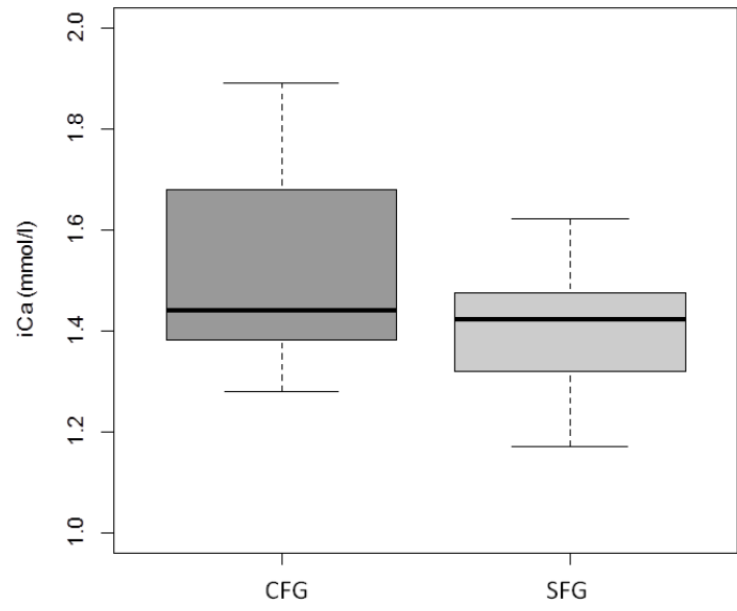

Figure2. Boxplot of characteristics of the SFG and CFG

conclusion that patients with simple fractures are not expected to have hypercalcemia as a consequence of a fracture. Comparing FG with $\mathrm{CG}$ it is possible to verify that differences among these groups are statically significant $(p=0.00)$ and that the occurrence of a fracture, no matter its nature, elevates $\left[\mathrm{iCa}^{2+}\right]$ above the reference range. This is an important result due to the fact that this way all patients with a diagnosed fracture should always be considered clinically hypercalcemic. This situation has to do with the release of $\mathrm{Ca}^{2+}$ through the lyse of hydroxyapatite crystals from the bone fraction, but also from the free fraction mobilization as a consequence of osteclasts' stimulated activity 
enhanced at fragment reabsorptions and fracture end tops. During the first 24 hours post-trauma an acute inflammatory response is established releasing strong and important inflammatory mediators, namely IL-1, IL-6 and TNF- $\alpha$, responsible among other things for the increased distance between top ends and certainly the indirect bone regeneration process ${ }^{16,17,18,19,20,21,22}$.

During the inflammatory process, injured bone cells induced by arachidonic metabolites via cyclooxygenases isoenzymes in response to the aggression process, are capable of expressing an intermediate prostaglandin $\left(\mathrm{PGH}_{2}\right)$ later converted to $\mathrm{PGE}_{2}$ through enzymatic reactions. These mediators promote osteoclats' formation, thus increasing its reabsorption activity. Osteoclasts adhere through their villi to the mineralized surface, creating a close space where bone reabsorption is started through secretion of $\mathrm{H}^{+}$, collagenase and other hydrolases (like acid phosphatase), and degradation of matrix hydroxyapatite through calcium salt crystals dissolution. In addition, trauma promotes acidosis, which will induce a rising of the $\left[\mathrm{iCa}^{2+}\right] \mathrm{ratio}^{10,17,18,23,24,25,26}$.

With $\mathrm{pH}$ fall, occurs the activation of proteolytic lysosome enzymes, namely $\mathrm{K}$ catepsine that is capable of assuring the organic matrix dissolution at low $\mathrm{pH}^{18}$. Despite the fact that $\left[\mathrm{iCa}^{2+}\right]$ average concentrations are higher for CFG than for SFG, these differences are not statistically significant which led us to conclude that the type of fracture has no influence on the $\left[\mathrm{iCa}^{2+}\right]$ concentrations. $\mathrm{CFG}$ has a tendency (although not statistically relevant) to present higher $\left[\mathrm{iCa}^{2+}\right]$ concentrations when compared to SFG, which is foreseeable due to the fact that the fracture area is usually larger and there are more than two top ends present. A larger fracture area necessarily means a higher number of involved osteoclasts, and thus higher expression of $\mathrm{PGE}_{2}$ due to elevated number of injured bone cells. All these will increase the hydroxyapatite crystal degradation process with more $\mathrm{Ca}^{2+}$ release into the bloodstream. We believe that increasing the sample size might confirm statistically significant differences between different fractures types as the obtained result $(p=0.06)$ is very close to a significant $\mathrm{p}$ value $(p<0.05)$. However and according to the results the type of fracture (either being simple or comminuted) does not play a relevant role to the existence of statistically significant differences on $\left[\mathrm{iCa}^{2+}\right]$ concentrations.
Nevertheless animals from group CFG always presented higher $\left[\mathrm{iCa}^{2+}\right]$ concentrations.

In practice, most clinicians may not immediately associate the clinical signs of patients with fractures with a hypercalcemia condition, and therefore, as a result of $\left[\mathrm{iCa}^{2+}\right]$ variations ${ }^{27,} 28$, 29. For both groups (SFG and CFG), it was possible to register some clinical signs associated with $\left[\mathrm{iCa}^{2+}\right]$ high 1 concentrations, with more expression in the CFG. Nevertheless, only for lethargy, and the PD/PU statistically significant differences were registered between the SFG and the CFG. Thus, apart from the existent type of fracture, these patients should always to be considered on a situation of middle hypercalcemia, particularly in cases of the CFG. Because of that, veterinary surgeons should be aware of the clinical signs associated with high $\left[\mathrm{iCa}^{2+}\right]$ concentrations on organic systems ${ }^{27,} 28$, $29,30,31$ therefore avoiding the use of drugs that promote the extracellular $\mathrm{Ca}^{2+}$ rising, such as, $\beta$ adrenergic agonists and amrinone in their medical protocols ${ }^{32,33}$. In case this happens it will lead to shorter and faster action potentials, as well as repolarization, thus promoting elevated cardiac frequency and contraction force (chronotropic and inotropic positive effects) with a consequent drop of arterial systemic blood pressure, and ventricular tachycardia that can culminate into fibrillation and sudden death. Moreover, drugs with hypercalcemic effects like thiazide diuretics that act by promoting hypernatruria at the convolute distal tubule and secondarily volume depletion, enhancing reabsorption of sodium and calcium at the convolute proximal tubule, should also be avoided $^{28,33,34}$.

Excess $\left[\mathrm{iCa}^{2+}\right]$ elimination through urinary tract can be achieved by incrementing diuresis through fluid therapy with simple saline solutions $\mathrm{NaCl} 0,9 \%$ given the fact that on this specific solution there is no calcium involved ${ }^{35}$.

This action can be improved adding an anse diuretic like furosemide although keeping in mind that this could also potentiate other blood components' depletion. Medically mild and severe hypercalcemia situations necessarily imply excess calcium elimination through fluid therapy with $\mathrm{NaCl} 0,9 \%$ and sodium bicarbonate administration as a way to increase calcium diuresis through increased sodium excretion ${ }^{17}$, 18. Another approach comprises reducing hydroxyapatite crystals dissolution through blood alkalinization, diuretic administration (i.e. furosemide) after adequate 
hydration, glucocorticoid administration and finally calcitonin or bisphosphonates administration, as all these substances will inhibit osteoclastic reabsorption.

Concluding, patients with fractures (both types SF and CF) always presented a higher average $\left[\mathrm{iCa}^{2+}\right]$ concentrations compared to patients suffered from trauma but without fractures. Therefore, SF and CF patients should be always considered to have a mild hypercalcemia condition until laboratory proven to the contrary. Clinical signs such as muscular shivering, vomiting, constipation, anorexia, PU/PD, and lethargy should be associated by the clinicians with the hypercalcemia condition. Although, no statistical significant differences were registered between the mean of $\left[\mathrm{iCa}^{2+}\right]$ concentration between $\mathrm{SF}$ and $\mathrm{CF}$, the last presented higher expression of the clinical signs than the first. As a result, the measurement of $\left[\mathrm{iCa}^{2+}\right]$ concentration should always be included on basic laboratory panel required by clinicians in patients with fracture, and the use of drugs that promote the extracellular $\mathrm{Ca}^{2+}$ rising should be avoid until the $\left[\mathrm{iCa}^{2+}\right]$ be monitored thus promoting therefore patients safety.

\section{ACKNOWLEDGMENTS}

The authors thank to CIISA - Interdisciplinary Centre of Research in Animal Health, of Faculty of Veterinary Medicine of Lisbon, of the University of Lisbon - Portugal (FMVULisboa); to ARC Publications Pvt - Veterinary Sciences for publishing the article with full wavier, and to Anjos of Assis Veterinary Medicine Center (CMVAA), Barreiro Portugal.

\section{REFERENCES}

[1] Wasserman RH, Kallfelz FA, Lust G.Bones, Joints and Synovial Fluid. In: Swenson MJ \& Reece WO. Dukes' Physiology of Domestic Animals, $11^{\text {th }}$ ed. Cornell, USA: Cornell University Press. 1993:536-564

[2] Hazewinkel H. Nutritional Management of Orthopedic Diseases. In: Fascetti A, Delaney S. Applied Veterinary Clinical Nutrition.West Sussex, UK: Willey-Blackwell.2012:125-156.

[3] Cunningham J. Textbook of Veterinary Physiology. $4^{\text {th }}$ ed.; St Louis, USA:Saunders Elsivier. 2007

[4] Piermattei D, Flo G, DeCamp C. Handbook of Small Animal Orthopedics and Fracture Repair, $4^{\text {th }}$ ed. Missouri, USA: Saunders Elsevier. 2006.

[5] Chai B, Tang X, Li H. Ultrastructural investigation of calcification and ossification in experimental fracture healing with special reference to osteogenic role of fibroblasts. Chin Med J (Engl). 1997 Apr; 110(4):274-8.

[6] Marsell, R., \& Einhorn, T. A. (2011). THE BIOLOGY OF FRACTURE HEALING. Injury, 42(6):551-555. http://doi.org/10.1016/ j.injury.2011.03.031

[7] Einhorn TA. The science of fracture healing. Journal of Orthopaedic Trauma. 2005; 19(10 Suppl):S4-6.

[8] Schenck P. Electrolyte Disorders: Ca-P and Mg. In: Ettinger SJ, Feldman EC. Textbook of Veterinary Internal Medicine. $7^{\text {th }}$ ed., Missouri, USA: Saunders Elsevier. 2010:299-314.

[9] Nelson RW, Delaney S, Elliott DA. Metabolic and Electrlyte Disorders. In: Nelson RW, Couto CG.Small Animal Internal Medicine. $4^{\text {th }}$ ed.Missouri, USA: Mosby Elsevier.:851-884).

[10] Barber JP. Investigation of Hypercalcaemia and Hipocalcaemia. In: Mooney CP, Peterson ME. BSAVA Manual of Canine and Feline Endocrinology. $3^{\text {rd }}$ ed., Gloucester, UK: BSAVA; 2004:26-42.

[11] Sakals, S., Peta, H. G. R., Fernandez, N. J., \& Allen, A. L. (2006). Determining the cause of hypercalcemia in a dog. The Canadian Veterinary Journal, 47(8): 819-821.

[12] Bergman PJ. Paraneoplastic syndromes. In: Withrow SJ, MacEwen EG, eds. Small Animal Clinical Oncology. 3rd ed. Philadelphia: Saunders, 2001:35-53.

[13] Capen CC. Tumors of the endocrine glands. In: Meuten DJ, ed. Tumors in Domestic Animals. 4th ed. Ames, Iowa: Iowa State Univ Pr, 2002:607-696.

[14] Feldman EC, Nelson RW. Canine and Feline Endocrinology and Reproduction, 3rd ed. Philadelphia: Saunders, 2004:660-715.

[15] Nelson RW, Turnwald GH, Willard MD. Endocrine, metabolic, and lipid disorders. In: Willard MD, Tvedten H, eds. Small Animal Clinical Diagnosis by Laboratory Methods. 4th ed. St. Louis: Saunders, 2004: 165-207.

[16] Ackermann MR. Chronic Inflammation and Wound Healing. In: McGavin MD, Zachary JF. Pathology Basis of Veterinary Disease. $4^{\text {th }}$ ed.,Missouri, USA: Mosby Elsevier. 2007:153192.

[17] Hoenderop J, Nilius B, Bindels R. Calcium Absorption Across Epithelia. Physiol Rev. 2005; 85:373-422.

[18] Kini U, Nandeesh BN. Physiology of Bone Formation, Remodeling and Metabolism. In: Fogelman I, Gnanasegaran G, Wall H. Radionuclide and Hybrid Bone Imaging Springer.2012:29-57.

[19] Gerstenfeld LC, Cullinane DM, Barnes GL, et al. Fracture healing as a post-natal developmental process: molecular, spatial, and 
temporal aspects of its regulation. Journal of Cellular Biochemistry. 2003; 88(5):873-84.

[20] Cho TJ, Gerstenfeld LC, Einhorn TA. Differential temporal expression of members of the transforming growth factor beta superfamily during murine fracture healing. Journal of Bone \& Mineral Research. 2002; 17(3):513-20.

[21] Sfeir C, Ho L, Doll BA, Azari K, Hollinger JO. Fracture repair. In: Lieberman JR, Friedlaender GE, editors. Bone regeneration and repair. Humana Press; Totowa, NJ: 2005: 21-44

[22] Kon T, Cho TJ, Aizawa T, et al. Expression of osteoprotegerin, receptor activator of NFkappaB ligand (osteoprotegerin ligand) and related proinflammatory cytokines during fracture healing. Journal of Bone \& Mineral Research. 2001;16(6):1004-14

[23] Dimitriou R, Tsiridis E, Giannoudis PV. Current concepts of molecular aspects of bone healing. Injury. 2005; 36(12):1392-404.

[24] Chawla, L. S., Nader, A., Nelson, T., Govindji, T., Wilson, R., Szlyk, S., ... Seneff, M. G. (2010). Utilization of base deficit and reliability of base deficit as a surrogate for serum lactate in the peri-operative setting. BMC Anesthesiology, 10, 16. http://doi.org/10.1186/ 1471-2253-10-16

[25] Chatrath, V., Khetarpal, R., \& Ahuja, J. (2015). Fluid management in patients with trauma: Restrictive versus liberal approach. Journal of Anaesthesiology, Clinical Pharmacology, 31(3), 308-316. http://doi.org/10.4103/09709185. 161664

[26] Pizzorno, J. (2015). Acidosis: An Old Idea Validated by New Research. Integrative Medicine: A Clinician's Journal, 14(1): 8-12.
[27] Shane E, Irani D. Hypercalcemia: Pathogenesis, Clinical Manifestations, Differential Diagnosis, and Management. American Society for Bones and Mineral Research, 2006:76-242

[28] Bell NH. Hypercalcemic and hypocalcemic disorders: Diagnosis and treatment. Nephron. 1979:147.

[29] Schenck PA, Chew DJ, Nagode LA, Rosol TJ. Disorders of calcium: hypercalcemia and hypocalcemia. In: DiBartola SP. Fluid, Electrolyte and Acid-base disorders in Small Animal Practice. $4^{\text {th }}$ ed.; St Louis, USA: Sanders 2012:120-194).

[30] Nelson RW, Delaney S, Elliott DA. Metabolic and Electrlyte Disorders. In: Nelson RN, Couto CG. Small Animal Internal Medicine; Missouri, USA: Mosby Elsevier $4^{\text {th }}$ ed.; 2009: 851-884.

[31] Gough A. Differential Diagnosis in Small Animal Medicine. Iwoa, USA: Blackwell Publishing; 2007.

[32] Detweiler DK. Regulation of the Heart. In: Swenson MJ. Dukes' Physiology of Domestic Animals. $11^{\text {th }}$ ed., Cornell, USA: Cornell University Press. 2009:170-183.

[33] Dias C, Carreira LM. Serum ionised calcium as a prognosis risk factor in the clinical course of pancreatitis in cats. J Feline Med Surg; 2015 Dec; 17(12):984-90. DOI: 10.1177/1098612X1 4564203

[34] Neiger R. Calcium haemostasis - assesment and therapy. Proceedings of the European Veterinary Conference Voorjaarsdagen, Amsterdam, Netherlands 2011:107-109.

[35] Buclin T, Cosma M, Appenzeller M, et al. Diet acids and alkalis influence calcium retention in bone. Osteoporos Int. 2001;12(6):493-499

Citation: Gonçalo Cabral Neto, Catarina Lavrador, Pedro Azevedo, L. Miguel Carreira. Serum Ionized Calcium Variations in Simple and Comminuted Fractures in the Dog's Appendicular Skeleton and Consequent Risks of a Hypercalcemic Condition. ARC Journal of Animal and Veterinary Sciences. 2017; 3(3):1-7. doi: dx.doi.org/ 10.20431/2455-2518.0303001.

Copyright: (C) 2017 Authors. This is an open-access article distributed under the terms of the Creative Commons Attribution License, which permits unrestricted use, distribution, and reproduction in any medium, provided the original author and source are credited. 